\title{
Testing Instrument: Model Building Self-Resilience to Drug Initiation and Habit
}

\author{
Rosmala Dewi ${ }^{1 *}$, Muhammad Bukhori Dalimunthe ${ }^{2}$, Raudah Zaimah Dalimunthe ${ }^{2}$ \\ $\{*$ ros_dw@unimed.ac.id \} \\ Universitas Negeri Medan, Medan, Indonesia ${ }^{1,2}$
}

\begin{abstract}
This study aims to examine the self-resilience model instrument for drug initiation and habituation. The instrument test sample came from high school students in Medan City, Asahan Regency, Batubara Regency, and Deliserdang Regency. An instrument testing analysis technique is reliability validity testing with Cronbach's alpha value. The results of the trial are obtained, there are several invalid items so that the item is deleted and not used. Where as for realiability testing is fulfilled for all variable research instruments.
\end{abstract}

Keywords: Instrument testing, self-resilience, initiation, drug abuse.

\section{Introduction}

The increasing prevalence of drug users in the city of Medan needs to get serious attention. Drug abuse is carried out by elementary, junior high, high school and university students, students with high and low socioeconomic backgrounds. Parents have high and low education, seen from the residence of students in the city and in the village already involved with drug abuse cases. Teenagers are the largest number because individuals who are unstable, easily anxious, do not have personal maturity, in the face of challenges and life problem, survive to achieve this life goal called self-resilience.

The impact of drug abuse causes promiscuity, free sex, will increasing abortion among adolescents this condition cannot be left, it must be immediately overcome. Some efforts have been made by various parties such as the National Narcotics Agency (BNN), police, schools, families, etc. However, such efforts have not been adequate, now all parties must have severe attention to drug prevention in all circles.

The BNN Special Region of Yogyakarta Province has also compiled an anti-drug self-defense instrument called the Anti-Drugs Scale (ADS) measuring instrument consisting of 3 dimensions; self-regulation, assertiveness, and reaching out are used to determine the ability of individuals in the face of encouragement, desire, or influence for drug abuse. In the initial stage ADS was prepared using 60 items of the Behaviorally Anchored Rating Scale (BARS) scale model item. Furthermore, it was tested on 1,997 respondents spread in Jakarta, Bogor, Depok, Tangerang, Bekasi and tested on high school students, students, employees and households. The result is 47 valid items for the long form type and 23 short form type items [1].

Self-resilience measurement using ADS uses a low sample of indications of using drugs, while the instrument of this research is aimed at teenagers who are indicated by drug initiation and adolescents who are actively using drugs. So that the purpose of this study to try out the instrument model to build self-resilience to the initiation and habituation of drugs so that it can be used to prevent drug use in future researchers.

\section{Methodology}

Validity is a measure that shows the validity of an instrument. A good instrument has a high value of validity, and vice versa. The purpose of testing validity is to show how far the validity of the instrument measures what the instrument wants to measure [2]. Djaali and Mulyono suggested that internal validity or item validity was shown by how far the results of the items were consistent with the results of the overall instrument measurement [3]. Therefore, item validity is reflected in the magnitude of the correlation coefficient between 
item scores and the instrument's total score. If the correlation coefficient between item scores and total instrument scores is positive and significant, then the item is considered valid based on the size of internal validity.

Reliability testing is a measurement of a group of homogeneous objects that can be trusted. A measurement result can be trusted if several times the measurement of the same subject group is obtained, the measurement results are relatively the same, as long as the aspect measured in the subject itself has not changed [2]. Reliability testing techniques are carried out in two ways, namely internally and internally. External reliability testing was obtained by retrying the questionnaire to the same respondents, then the results of the first trial were correlated with the results of the second trial so that this technique was also called the single test double trial technique. Of course, external reliability testing requires a lot of time and money. So as to overcome this, internal reliability testing is carried out, where internal reliability testing is obtained by analyzing data from one measurement result [4].

Several previous studies have tried to focus on research on the topic of drug abuse prevention. The National Narcotics Agency has formed a Community Prevention and Empowerment Agency (P2M) that oversees the results of the implementation of anti-drug activist action plans. Various P2M activities have been carried out to encourage people to avoid drug abuse. The establishment of the Anti Narcotics Task Force is an effort to reduce the prevalence of drug abuse and media facilities to convey information about drugs to the public [5]. In addition to the establishment of institutions, other efforts that can be done come from families. Where the family has a very urgent function to counteract the negative influence of the environment around family members. The results of Yusoff and Don's research explain that a good family function can increase adolescent self-resilience so that they can refrain from negative behavior [6].

Instrument test respondents consisted of high school students from Medan City, Asahan Regency, Batubara Regency, and Deliserdang Regency. Selection of respondents based on information provided by the teacher from sharing harmful activities carried out by students during school. Information data collection is carried out incidentally without being planned to avoid anxiety and rejection from students, so data collection efforts for each school are repeated.

Efforts to obtain a good instrument are tested for validity by the corrected item-total correlation method using the product moment formula the way that is done by measuring the correlation between the score of the item statement and the overall statement score. The calculation is done through the SPSS program. Item validity is set at an alpha level of 5\%. Invalid instruments are not used in research. Instrument reliability was tested with the Cronbach alpha method.

\subsection{Validity Test}

Validity test aims to see whether the instrument used is valid or indeed in accordance with the measured variables. A valid instrument means a measuring instrument used to obtain valid data. Valid means that the instrument can be used to measure what should be measured [7]. The instrument validity testing technique used Cronbach alpha coefficient which is an internal consistency score model based on the average correlation between statement items. If a question item has a Cronbach alpha value in the alpha if item deleted column greater than the alpha Cronbach value of the entire measurement scale, then the item must be deleted or the item must be revised if the item is theoretically needed to be analyzed.

\subsection{Reliability Test}

Reliability testing is used to determine the consistency of the measuring instrument, whether the measuring device used is reliable and remains consistent if the measurement is repeated. The method used is Cronbach alpha. If the Cronbach alpha value is greater than 0.6 , the instrument is reliable [7]. Then explained the validity and reliability of each variable. Research variables that will reveal drug initiation and habituation are described in the instrument lattice of each variable described in the following table.

\section{a. The Effectiveness of Information Technology Utilization}

Tabel 1. The Effectiveness of Information TechnologyUtilization Instrument

\begin{tabular}{clcc}
\hline Indicators & Descriptors & \multicolumn{2}{c}{ Item Numbers } \\
\cline { 3 - 4 } & & + & $(-)$ \\
\hline Ease of identifying data & IT provides convenience in identifying data in & $1,2,3,12,13,1$ & 4 \\
\hline
\end{tabular}




\begin{tabular}{|c|c|c|c|}
\hline \multirow[t]{2}{*}{ Indicators } & \multirow[t]{2}{*}{ Descriptors } & \multicolumn{2}{|c|}{ Item Numbers } \\
\hline & & + & $(-)$ \\
\hline & the education world & 8 & \\
\hline & IT makes it easy to build socialization & $5,6,7$ & - \\
\hline & IT makes it easy to find out about drugs & 8,10 & 9,11 \\
\hline & IT provides ease of finding out about pornography & 14,17 & 15,16 \\
\hline Subtotal & & 12 & 6 \\
\hline \multirow[t]{4}{*}{ Ease of accessing data } & $\begin{array}{l}\text { T makes it easy to access data needed in the world } \\
\text { of education }\end{array}$ & $\begin{array}{l}19,20,21,22,3 \\
6,37,38\end{array}$ & \\
\hline & $\begin{array}{l}\text { Ease of giving and receiving information through } \\
\text { social media (social media) }\end{array}$ & $\begin{array}{l}23,24,25,26,2 \\
7\end{array}$ & 30,31 \\
\hline & $\begin{array}{l}\text { Facilitate and facilitate the interaction of drug } \\
\text { trafficking }\end{array}$ & - & 28,29 \\
\hline & $\begin{array}{l}\text { Facilitate the distribution of pornographic } \\
\text { images/videos }\end{array}$ & - & $32,33,34,35$ \\
\hline Subtotal & & 12 & 8 \\
\hline \multirow[t]{4}{*}{$\begin{array}{l}\text { Number of individual } \\
\text { users }\end{array}$} & $\begin{array}{l}\text { Having a personal account in IT makes it easy and } \\
\text { improves education }\end{array}$ & $39,40,41,42$ & - \\
\hline & $\begin{array}{l}\text { Users of social media account significantly } \\
\text { influence each }\end{array}$ & $43,44,45$ & 46,47 \\
\hline & $\begin{array}{l}\text { More and more users of social media accounts } \\
\text { make it easy to connect with drug sales }\end{array}$ & 48,49 & 50 \\
\hline & $\begin{array}{l}\text { More and more users / users of Medos accounts } \\
\text { make it easy to connect with pornographic sites }\end{array}$ & - & $51,52,53,54$ \\
\hline Subtotal & & 8 & 8 \\
\hline \multirow[t]{4}{*}{ Area Coverage } & $\begin{array}{l}\text { Various educational science data obtained from } \\
\text { various countries }\end{array}$ & $63,64,70$ & - \\
\hline & $\begin{array}{l}\text { Socialization among fellow IT users is not limited } \\
\text { by time and place }\end{array}$ & $55,56,5760$ & 58 \\
\hline & $\begin{array}{l}\text { The interaction between drug trafficking between } \\
\text { dealers and buyers is not limited by place }\end{array}$ & - & $59,61,62$ \\
\hline & $\begin{array}{l}\text { Get various pornographic sites from unlimited } \\
\text { sources. }\end{array}$ & 69 & $65,66,67,68$ \\
\hline Subtotal & & 8 & 8 \\
\hline Total & & 40 & 30 \\
\hline
\end{tabular}

\section{b. Drug Hazard Awareness Education}

Tabel 2. Drug Hazard Awareness Instrument

\begin{tabular}{|c|c|c|c|}
\hline \multirow[t]{2}{*}{ Indicators } & \multirow[t]{2}{*}{ Deskcriptors } & \multicolumn{2}{|c|}{ Item numbers } \\
\hline & & + & $(-)$ \\
\hline \multirow{4}{*}{$\begin{array}{l}\text { Sources of information } \\
\text { about the dangers of } \\
\text { drugs }\end{array}$} & Sources of information come from parents & 1,2 & - \\
\hline & Sources of information come from school teachers & 3,4 & - \\
\hline & $\begin{array}{l}\text { Sources of information come from religious } \\
\text { teachers }\end{array}$ & $5,6,7$ & - \\
\hline & Sources of information come from friends & 1 & 1 \\
\hline Subtotal & & 8 & 1 \\
\hline \multirow{3}{*}{$\begin{array}{l}\text { Information about } \\
\text { hazards, impacts and } \\
\text { types of drugs }\end{array}$} & Information obtained from school teachers & $12,13,14,15$ & - \\
\hline & Information obtained from religious teachers & $16,17,18$ & - \\
\hline & Information obtained from friends & $10,11,19,20$ & 21 \\
\hline Subtotal & & 11 & 1 \\
\hline Behavior avoids the & Examples of avoiding the dangers of drugs from & 4 & 1 \\
\hline
\end{tabular}




\begin{tabular}{llcc}
\hline \multicolumn{1}{c}{ Indicators } & \multicolumn{1}{c}{ Deskcriptors } & \multicolumn{2}{c}{ Item numbers } \\
\cline { 2 - 3 } dangers of drugs & parents & + & \\
\cline { 2 - 3 } & $\begin{array}{l}\text { Examples of drug avoidance behavior from school } \\
\text { teachers }\end{array}$ & 31 & - \\
\cline { 2 - 3 } & $\begin{array}{l}\text { Examples of avoiding drug dangers from religious } \\
\text { teachers }\end{array}$ & $27,28,29$ & - \\
\cline { 2 - 4 } & $\begin{array}{l}\text { Examples of avoiding the dangers of drugs from } \\
\text { friends }\end{array}$ & $32,33,34,35$ & 26 \\
\hline Subtotal & & $\mathbf{1 2}$ & $\mathbf{2}$ \\
\hline Total & & $\mathbf{3 1}$ & $\mathbf{4}$ \\
\hline
\end{tabular}

\section{c. Life Skill}

Tabel 3. Life Skill Instrument

\begin{tabular}{|c|c|c|c|}
\hline \multirow[t]{2}{*}{ Indicators } & \multirow[t]{2}{*}{ Descriptors } & \multicolumn{2}{|c|}{ Item numbers } \\
\hline & & + & $(-)$ \\
\hline Comunication & $\begin{array}{l}\text { Communication skills in conveying intentions to } \\
\text { achieve goals }\end{array}$ & $\begin{array}{c}1,3,4,5,6,7,8 \\
9,10,11,12,1 \\
3,14\end{array}$ & 2 \\
\hline Subtotal & & 13 & 1 \\
\hline Altruism & Behavior that prioritizes the interests of others & $\begin{array}{c}115,16,17,18 \\
19,20,21,22, \\
23,24,25,26\end{array}$ & - \\
\hline Subtotal & & 12 & $\mathbf{0}$ \\
\hline Making decision & Skills to make decision in life & $\begin{array}{c}27,28,29,30, \\
31,32,33,34, \\
35,36,37,38, \\
39,40,41\end{array}$ & - \\
\hline Subtotal & & 15 & $\mathbf{0}$ \\
\hline Responsible citizen & Attitudes as citizens who comply with regulations & $\begin{array}{c}42,43,44,45, \\
46,47,48,49, \\
50,51,52,53, \\
54,55,56,57, \\
58 \\
\end{array}$ & - \\
\hline Subtotal & & 17 & $\mathbf{0}$ \\
\hline Teamwork & Skill to work in a group to obtain a goal & $\begin{array}{l}59,60,61,62 \\
63,64,64,66 \\
\end{array}$ & - \\
\hline Subtotal & & 8 & $\mathbf{0}$ \\
\hline Critical thinking & The ability to analyze facts to maintain ideas & $\begin{array}{c}67,68,69,70, \\
71,72,73,74, \\
75,76,77,78, \\
79,80,81,82, \\
83 \\
\end{array}$ & - \\
\hline Subtotal & & 17 & $\mathbf{0}$ \\
\hline Leadership & Skill to influence others in purpose to obtain a goal & $\begin{array}{c}84,85,86,87 \\
88,89\end{array}$ & - \\
\hline Subtotal & & 6 & $\mathbf{0}$ \\
\hline Problem solving & $\begin{array}{l}\text { Thinking skills in providing solutions to problem } \\
\text { solving }\end{array}$ & $\begin{array}{l}90,91,92,93, \\
94,95,96,97, \\
98,99,100,10 \\
1,102,103,10 \\
4,105,106,10\end{array}$ & - \\
\hline
\end{tabular}




\begin{tabular}{|c|c|c|c|}
\hline \multirow[t]{2}{*}{ Indicators } & \multirow[t]{2}{*}{ Descriptors } & \multicolumn{2}{|c|}{ Item numbers } \\
\hline & & + & $(-)$ \\
\hline & & 7 & \\
\hline Subtotal & & 18 & $\mathbf{0}$ \\
\hline Self esteem & $\begin{array}{l}\text { The attitude of individual perception about his } \\
\text { condition }\end{array}$ & $\begin{array}{l}108,110,111 \\
114,115,117 \\
\end{array}$ & $\begin{array}{l}109,112,113 \\
116\end{array}$ \\
\hline Subtotal & & 7 & 3 \\
\hline Personal responsibility & $\begin{array}{l}\text { The attitude of self-awareness of the behavior } \\
\text { carried out in the community }\end{array}$ & $\begin{array}{l}118,119,120 \\
121,122,123 \\
\end{array}$ & - \\
\hline Subtotal & & 6 & $\mathbf{0}$ \\
\hline Total & & 119 & 4 \\
\hline
\end{tabular}

\section{d. Spritiual Guidance}

Tabel 4. Spiritual Guidance Instrument

\begin{tabular}{|c|c|c|c|}
\hline \multirow[t]{2}{*}{ Indicators } & \multirow[t]{2}{*}{ Descriptors } & \multicolumn{2}{|c|}{ Item numbers } \\
\hline & & + & $(-)$ \\
\hline Sincerity & $\begin{array}{l}\text { Sincerity, honesty, willingness to expect God's } \\
\text { blessing }\end{array}$ & $1,2,3,4,5,6$ & - \\
\hline Subtotal & & 6 & $\mathbf{0}$ \\
\hline Patience & Withstand trials, not irritable, and unhurried & 7,8 & 9,10 \\
\hline Subtotal & & 2 & 2 \\
\hline Calmness & $\begin{array}{l}\text { The atmosphere of inner human life or human self } \\
\text { which consists of feelings that cause humans to be } \\
\text { restless }\end{array}$ & $\begin{array}{l}12,15,16 \\
, 19,20,21\end{array}$ & $\begin{array}{c}11,13,14, \\
17,18,\end{array}$ \\
\hline Subtotal & & 6 & 5 \\
\hline $\begin{array}{l}\text { Recognizing its } \\
\text { existence as a creature } \\
\text { of God }\end{array}$ & $\begin{array}{l}\text { The ability to resolve yourself with others and the } \\
\text { environment is aware that all human activities are } \\
\text { following the provisions of God Almighty }\end{array}$ & $\begin{array}{c}24,25,26,27 \\
29,30\end{array}$ & $22,23,28$ \\
\hline Subtotal & & 6 & 3 \\
\hline Total & & 20 & 10 \\
\hline
\end{tabular}

\section{e. Self Resilience to Drug Initiation and Habit}

Tabel 5. Self Resilience to Drug Initiation and Habit Instrument

\begin{tabular}{llcc}
\hline \multicolumn{1}{c}{ Indicators } & \multicolumn{1}{c}{ Descriptors } & \multicolumn{2}{c}{ Item numbers } \\
& & + & $(-)$ \\
\hline Tenacity & Accuracy recognizes the selected activity & $1,2,3,4,6$ & 5 \\
\hline Subtotal & & $\mathbf{5}$ & $\mathbf{1}$ \\
\hline Toughness & Tough/strong in facing challenges & $7,8,9,12$ & 10,11 \\
\hline Subtotal & & $\mathbf{4}$ & $\mathbf{2}$ \\
\hline $\begin{array}{l}\text { Ability to develop self- } \\
\text { strength }\end{array}$ & Able to develop self-strength against threats & $13,14,15$, & 18 \\
\hline Subtotal & & 16,17 & $\mathbf{1}$ \\
\hline $\begin{array}{l}\text { Ability to face } \\
\text { challenges }\end{array}$ & $\begin{array}{l}\text { Able to face various challenges that damage self- } \\
\text { potential }\end{array}$ & $19,20,21$, & 23,24 \\
\hline Subtotal & & 22 & $\mathbf{4}$ \\
\hline $\begin{array}{l}\text { The ability to face the } \\
\text { interference that comes }\end{array}$ & $\begin{array}{l}\text { Able to deal with interference coming from inside } \\
\text { and outside of him }\end{array}$ & $25,26,27$, & 30 \\
\hline $\begin{array}{l}\text { Subtotal } \\
\text { Total }\end{array}$ & & 28,29 & $\mathbf{5}$ \\
\hline
\end{tabular}




\section{Result and Discussion}

\subsection{Instrument Testing Effectiveness of Information Technology Utilization Variables}

Based on the tests conducted on 82 samples obtained the validity of the instrument that all items totaling 70 items were declared valid because there was no Cronbach's alpha if item deleted value higher than the value 0.993. Likewise, reliability testing stated that the instrument was reliable to use, this was because the value of Cronbach's alpha was 0.993 greater than 0.6 .

\subsection{Testing Instrument Variable Education for Narcotics Hazard Awareness}

Based on the tests conducted on 97 samples, the validity of the instrument was found that there were six invalid items, namely 9, 19, 21, 26, 30, and 32, this is because there is a Cronbach's alpha if item deleted the value that is greater than the value 0.983 . Invalid instrument items will be discarded and not used for research data collection. Reliability testing stated that the instrument is reliable to use, this is because the value of Cronbach's alpha is 0.983 greater than 0.6 .

\subsection{Testing Life Skills Variable Instruments}

Based on the tests carried out on 66 samples, the validity of the instrument was found that there were 3 invalid items, namely number 1, 2, and 113, this is because there is a Cronbach's alpha if item deleted value that is greater than the 0.965 value. Invalid instrument items will be discarded and not used for research data collection. Reliability testing stated that the instrument is reliable to use, this is because the value of Cronbach's alpha is 0.965 higher than 0.6 .

\subsection{Testing Spiritual Guidance Variable Instruments}

Based on testing conducted on 83 samples, the validity of the instrument was found that the invalid items were 5 items, namely numbers $8,10,14,20$, and 21 , this is because there is a Cronbach's alpha if item deleted value higher than the value 0.935. Invalid instrument items will be discarded and not used for research data collection. Reliability testing stated that the instrument is reliable to use, this is because the value of Cronbach's alpha of 0.935 is greater than 0.6 .

\subsection{Testing Instrument for Variable Self-Resilience to Drug Initiation and Habit}

Based on the tests conducted on 77 samples obtained the validity of the instrument that invalid items as many as 9 items, namely numbers $5,10,11,15,17,18,23,24$, and 30 , this is because there is a value of Cronbach's alpha if item deleted which is greater than the value of 0.846 . Invalid instrument items will be discarded and not used for research data collection. Reliability testing stated that the instrument is reliable to use, this is because the value of Cronbach's alpha is 0.846 greater than 0.6 .

The model builds self-resilience to drug initiation and habituation consisting of 5 (five) variables, namely the effectiveness of the use of information technology, awareness of the dangers of drugs, life skills, spiritual guidance, self-resistance to drug initiation and habituation.

Instrument test respondents came from high school students in Medan City, Asahan Regency, Batubara Regency, and Deliserdang Regency. Selection of respondents based on information provided by the teacher from sharing negative activities carried out by students during school. This negative behavior is a strong presumption that the student has been contaminated by the behavior of drug users.

The results of testing instruments can be continued for research models to build self-resilience to drug initiation and habituation. Each research variable instrument has a Cronbach's alpha value if different items are deleted. Valid items if the value is smaller than Cronbach's Alpha will be used for research, while invalid items will be deleted from the list of research instruments.

Furthermore, the research instrument will be disseminated to the research object for the process of data collection and analysis to build a model of self-resilience towards drug initiation and habituation. The model will be used as a preventive measure against adolescents who take the initiative to use drugs and recovery measures for perpetrators who are used to using drugs. 


\section{Conclusion}

The conclusions of the study found that: 1) testing the validity of the effectiveness of the use of information technology obtained 70 valid items; 2) testing the validity of education awareness of the dangers of drugs obtained 29 valid items; 3) testing the validity of life skills obtained 120 valid items; 4) testing the validity of spiritual guidance obtained 25 valid items; 5) testing the validity of self-resistance against drug initiation and habituation obtained 21 valid items; and 6) all research instruments are reliable.

\section{References}

[1] S. Arikunto, Prosedur penelitian: Suatu pendekatan praktik. Rineka Cipta, 1992.

[2] Cahaya, Ukur Ketahanan Diri Dari Narkoba Dengan ADS. Badan Narkotika Nasional Provinsi Daerah Istimewa Yogyakarta., 2017.

[3] R. Dewi, "Penelitian Pendidikan (Desain Emperikal dan PTK)." Pascasarjana Unimed, 2012.

[4] Yogyakarta.bnn.go.id,http://yogyakarta.bnn.go.id/media-publikasi/artikel/142-ukur-ketahanan-diri-dari-narkobadengan-ads. .

[5] P. Djaali and Mulyono, Pengukuran dalam Bidang Pendidikan. Jakarta: Grasindo, 2008.

[6] Sugiyono, Metode penelitian pendidikan:(pendekatan kuantitatif, kualitatif dan R \& D). Alfabeta, 2008.

[7] A. Seftya, . 2017. Satgas Narkoba dari Perspektif Mahasiswa. Badan Narkotika Nasional Provinsi Daerah Istimewa Yogyakarta. 2017. 
